\title{
A imagem do corpo e opção pelos fracos (1 Cor 12,14-27): embrião da Teologia da Libertação
}

\author{
The image of the body and option for the weak \\ (1 Cor 12:14-27): \\ embryon of the Theology of Liberation
}

Joel Antônio Ferreira

\section{Resumo}

"Os membros do corpo que parecem mais fracos são os mais necessários, e aqueles que parecem menos dignos de honra do corpo são os que cercamos de maior honra, e nossos membros que são menos decentes, nós os tratamos com mais decência" (1 Cor 12,22-23). Esta pequena citação retrata a espinha dorsal que sustentou todo o texto da Primeira Epístola aos Coríntios: a opção preferencial pelos "mais fracos". Nessa metáfora do corpo humano, Paulo estava falando da comunidade cristã de Corinto. Ao definir os mais fracos como "menos dignos de honra", como "menos decentes", o Apóstolo estava, possivelmente, olhando os pobres e os escravos de Corinto e de todo o Império Romano. Diante da sociedade profundamente injusta, o Apóstolo mostrou a sua posição: Os mais fracos são os mais necessários. Os menos dignos de honra, nós os cercamos de mais honra. Os menos decentes, nós os tratamos com mais decência. A opção existencial e pastoral de Paulo pelos "fracos", os que estavam abaixo da pirâmide imperial, era claríssima. Aqui temos um dos embriões da Teologia da Libertação.

Palavras-chave: Fortes. Fracos. Corpo. Comunidade. 


\begin{abstract}
"The members of the body that seem to be weaker are most needed, and those who seem less worthy of honor are the body that surround the greater honor, and our members who are less decent, we treat them with more decency" (1 Cor 12.22-23). This little quote portrays the backbone that supported the entire text of the First Epistle to the Corinthians, the preferential option for the "weaker". In this metaphor of the human body, Paul was speaking of the Christian community of Corinth. When defining the weakest as "less worthy of honor" as "less decent", was possibly looking the poor and the slaves of Corinth and the entire Roman Empire. Given the deeply unjust society, the Apostle showed his position: The weakest are the most needed. The less worthy of honor, we surrounded them more honor. The least decent, we treat them with more decency. The existential and pastoral option for "weak", those below the imperial pyramid, was crystal clear. Here we have one of the embryos of liberation theology.
\end{abstract}

Keywords: Strong. Weak. Body. Community.

\title{
Introdução
}

A partir da Epístola aos Coríntios e dos dados da história, podemos observar algumas contradições sociais no ambiente daquela metrópole. Havia, na cidade de Corinto, muitas tensões: "judeus e gregos" (1 Cor 1,18-31; 12,13), "livres e escravos" (1 Cor 7,21-23; 12,13), "ricos e pobres" (1 Cor 11,22). As sociedades romanas e gregas se organizavam a partir de um topo piramidal, onde as relações de poder eram controladas pelas elites imperiais.

Era uma pirâmide de relações de poder onde, no topo, estavam os deuses. Abaixo dos deuses, estava o imperador. Em seguida, os sacerdotes, os aristocratas (senadores em Roma e o patronato espalhado por todo o Império), a ordem equestre e os cavaleiros publicanos (plebeus enriquecidos) e clientes plebeus (homens do povo que se tornaram nobres). Mais abaixo, os cidadãos, em geral, romanos ou ligados a eles ${ }^{1}$.

$\mathrm{Na}$ base da pirâmide, os libertos, quase sempre estrangeiros que conse-

${ }^{1}$ CROSSAN, J. D.; REED, J. L. Em busca de Paulo: como o apóstolo de Jesus opôs o Reino de Deus ao Império Romano. São Paulo: Paulinas, 2007, toda a obra. 
guiam os títulos. Pertenciam a esse inumerável grupo os trabalhadores que não eram escravos. Abaixo da base: os escravos (a grande população estrangeira do Império).

Roma movimentava toda a sua economia na base do "Modo de Produção Escravagista Romano". É óbvio, como veremos, principalmente, por causa do modo de produção escravagista, a distância entre os "livres e escravos" era abissal $^{2}$. E, proximamente a esta contradição, a assimetria "ricos e pobres" (1 Cor 11,22) era visível. Entre os poucos ricos, milhares de pobres e escravos. Havia contrastes sociais gravíssimos.

E dentro da ekklesía? Não está claro se na Igreja de Corinto estivessem judeus convertidos. Tambasco disse que na Cosmopolita Corinto havia uma interessante comunidade judaica, que tinha uma presença religiosa, um padrão moral e uma vida familiar significativa. Segundo ele, muitos judeus, ao serem expulsos de Roma pelo imperador Claudio, refugiaram-se no paraíso de Corinto (At 18,2). Os Atos dos Apóstolos falaram de Crispo, um chefe da Sinagoga que foi batizado (At 18,8). A Primeira Epístola aos Coríntios aludiu a Sóstenes (1 Cor 1,1) um antigo líder judeu. Outros, como Priscila e Áquila se tornaram cristãos, antes da expulsão de Roma e se tornaram amigos de Paulo, tanto na Pastoral como no trabalho (comércio de tendas). Depois surgiu um judeu vindo de Alexandria, chamado Apolo, que se tornou amigo de Paulo e era um grande pregador ${ }^{3}$.

Paulo apontou um desnível, ou seja, a presença, até dentro das pequenas comunidades, dos "fortes e fracos" (1 Cor 1,26-31) e dos "grupos e grupos" (1 Cor 1-4). O grande problema é que os "fortes" e pessoas que colocavam o seu "grupo" ou partido como opção, imitavam o jeito das elites romanas, gregas e coríntias. Assim, criavam facções. Usavam, a exemplo da sociedade greco-romana, a Igreja para se autopromoverem.

Quem eram os "fortes"? Conforme Barbaglio4, eram "cristãos iluminados" ou eufóricos ou espiritualistas/esclarecidos que não acreditavam nos ídolos. Achavam-se livres e se vangloriavam como sábios $(1$ Cor 4,10$)$ e espirituais (1 Cor 3,1). Também entre os fortes existiam os glossolálicos, os eufóricos, ufanistas e espiritualistas, as mulheres emancipadas (1 Cor 12-14),

\footnotetext{
${ }^{2}$ BRADLEY, K. R. Slaves and Masters in the Roman Empire. A Study in Social Control. New York: Osford University Press, 1987, toda a obra.

${ }^{3}$ TAMBASCO, Anthony J. In the Days of Paul. The Social World and Teaching of the Apostle. Eugene, Oregon: Wipf \& Stock, 2006, pp. 65-66.

${ }^{4}$ BARBAGLIO, G. As Cartas de Paulo (I). São Paulo: Loyola, 1989, p. 178.
} 
os exibicionistas fanáticos (angélicos), os negadores da ressurreição (1 Cor $15)$, os grupelhos que tinham recursos econômicos e comiam à vontade, em detrimento dos pobres (1 Cor 11,17-34). Os fortes, em geral, não tinham o espírito comunitário. Eles eram minoria. Tinham um nível social melhor. Paulo os chamou de "carnais", significando que eram infantis, por se acharem "perfeitos" (1Cor 2,6).

Sobre os "fracos", eram cristãos simples e humildes que acolhiam a mensagem com sinceridade ${ }^{5}$. Porém, não tinham aprofundamento intelectual e pouca solidez prática. Muitos tinham complexos de inferioridade. Eram desprezados pelos “fortes". Não tinham voz no grupo e, praticamente, nada possuíam. Os fracos, parece, eram a maioria na comunidade cristã. Eram cristãos pobres, de baixa condição social (possivelmente, também, os escravos). Fiéis simples. Não tinham prestígio e, por isso, sem voz também na Igreja. Sabe-se de duas mulheres que se sobressaíram na ekklesía: Febe, diaconisa da Igreja de Cencreia ( $\mathrm{Rm} \mathrm{16,1-2).} \mathrm{Cencreia} \mathrm{era} \mathrm{um} \mathrm{dos} \mathrm{dois} \mathrm{portos} \mathrm{de} \mathrm{Corinto} \mathrm{que}$ movimentava todo o comércio que vinha e ia para Atenas, Éfeso, Antioquia e o Oriente; a outra era Cloé: tinha alguns negócios ${ }^{6}$. Foi de sua casa que chegaram as notícias para Paulo sobre o andamento da Igreja de Corinto.

Paulo evangelizou, preferencialmente, os pobres de Corinto. A sua pregação aos fracos era cheia de esperança (1 Cor 1,26-31; 2,3; 2,4-7; 4,10-13; $8,7-13 ; 9,19-27 ; 10,23-11,1 ; 12,12-26)$. A comunidade cristã precisava se organizar, a partir de baixo (fracos, escravos, humildes, sem projeção, vis, marginalizados).

Qual foi o grande "projeto" de Paulo neste "olhar ideológico e religioso"? A luta de Paulo foi de conscientizar os coríntios cristãos de que não podiam reproduzir as desigualdades e injustiças romanas.

Com a leitura sociológica pelo modelo conflitual ou dialético (sociologia crítica), procurar-se-á olhar o "lugar social" dos desvalidos que pertenciam à Igreja de Corinto, para ouvir a voz daqueles que não tinham espaço e vez. Eram os da "margem". Os "fracos" nunca apareciam, porém, Paulo, entendendo a preferência de Deus, tinha-os como opção pastoral e social (1 Cor 12,22-23). O "lugar social" dos esquecidos se torna um espaço primordial".

\footnotetext{
${ }^{5}$ BARBAGLIO, G. As Cartas de Paulo (I), pp. 182-185.

${ }^{6}$ FERREIRA, Joel A. Primeira Epístola aos Coríntios. São Paulo: Fonte Editorial, 2013, p. 28.

${ }^{7}$ Por exemplo, em 1 Coríntios temos o famoso texto da Ceia do Senhor (11,17-34). Por trás do profundo anúncio da Ceia, o leitor precisa olhar, por trás das palavras, as divisões sociais claras dentro de um grupo que se dizia cristãos e que, no entanto, repetiam, no momento da Ceia, os
} 
Quando o Apóstolo disse que tratava os fracos "com mais decência", estava, de fato, fazendo a verdadeira Teologia da Libertação: a opção clara e decidida pelos injustiçados, pelos oprimidos e infelizes de qualquer sistema opressor.

\section{2,14-27: A imagem do corpo e a opção pelos fracos}

${ }^{14} \mathrm{O}$ corpo não se compõe de um só membro, mas de muitos. ${ }^{15}$ Se o pé disser: "Mão eu não sou, logo não pertenço ao corpo", nem por isto deixará de fazer parte do corpo. ${ }^{16} \mathrm{E}$ se a orelha disser: "Olho eu não sou, logo não pertenço ao corpo", nem por isto deixará de fazer parte do corpo. ${ }^{17} \mathrm{Se}$ o corpo todo fosse olho, onde estaria a audição? Se fosse todo ouvido, onde estaria o olfato? ${ }^{18}$ Mas Deus dispôs cada um dos membros no corpo, segundo a sua vontade. ${ }^{19}$ Se o conjunto fosse um só membro, onde estaria o corpo ${ }^{20}$ Há, portanto, muitos membros, mas um só corpo. ${ }^{21}$ Não pode o olho dizer à mão: "Não preciso de ti" nem tampouco pode a cabeça dizer aos pés: "Não preciso de vós". ${ }^{22}$ Pelo contrário, os membros do corpo que parecem mais fracos são os mais necessários, ${ }^{23} \mathrm{e}$ aqueles que parecem menos dignos de honra do corpo são os que cercamos de maior honra, e nossos membros que são menos decentes, nós os tratamos com mais decência; ${ }^{24}$ os que são decentes não precisam de tais cuidados. Mas Deus dispôs o corpo de modo a conceder maior honra ao que é menos nobre, ${ }^{25}$ a fim de que não haja divisão no corpo, mas os membros tenham igual solicitude uns com os outros. ${ }^{26} \mathrm{Se}$ um membro sofre, todos os membros compartilham o seu sofrimento; se um membro é honrado, todos os membros compartilham a sua alegria. ${ }^{27}$ Ora, vós sois o corpo de Cristo e sois os seus membros, cada um por sua parte.

Este é um texto vital para se entender toda a Epístola aos Coríntios. Qual é o fulcro de 1Cor 12,14-27? O Apóstolo colocou esta metáfora dentro do seguinte contexto: os cristãos de Corinto tinham diversas dúvidas sobre os “dons espirituais", a respeito da teologia do Espírito Santo e como, na prática, deveriam ser resolvidas as tensões dentro da ekklesía.

mesmos esquemas dos banquetes dos patronatos romanos que, também, repetiam os banquetes do centro do Império. A perícope queria falar da Ceia do Senhor? Sim. No entanto, ela sinalizou que a Ceia do Senhor, para os cristãos que viviam debaixo do jugo do império romano, devia ser a experiência do igualitarismo e da vida do amor, com todas as suas consequências (MURPHY-O'CONNOR, Jerome. "Primeira Carta aos Coríntios". In: BROWN, Raymond E.; FITZMYER, Joseph A.; MURPHY, Roland E. (Eds.). Novo Comentário Bíblico São Jerônimo: Novo Testamento e Artigos Sistemáticos. Santo André/São Paulo: Academia Cristã/Paulus, 2011, p. 476). Esse texto foi uma crítica severa aos que criavam assimetrias dentro da ekklesía. 
Toda a Epístola, desde o início, foi sendo enriquecida pelas orientações de Paulo em torno dos inumeráveis conflitos dos cristãos de Corinto. Já em 1 Cor 1,10-4,21 o leitor já se deparou com as descrições das divisões dentro da comunidade. Foi nesta parte, que ele mostrou que a sabedoria cristã estava num nível além da sabedoria do mundo. Ao anunciar o crucificado, Paulo focou na escolha de Deus pelos fracos, vis e desprezados. A mão de Paulo, nesta parte, não teve dúvidas. Aos poucos, ele foi desenvolvendo a reflexão que mostrava que, na raiz dos conflitos, estava a postura assimétrica de alguns elementos da comunidade. Esses se colocavam em posturas semelhantes aos discricionários gregos e romanos. O Apóstolo sempre se indignou com o comportamento daqueles que, dentro da Igreja, agiam como se fossem mais importantes que os marginalizados.

Então, como aqui no capítulo 12, já na primeira parte, ele apontou que a superação das divisões só podia acontecer na mentalidade do Espírito Santo, que fazia o seu Templo dentro da comunidade, sem facções. Por isso, a busca da sabedoria se dava na comunidade de fé. Se as lideranças como Cefas, Apolo e ele não eram proprietários da ekklesía, muito menos os membros podiam se colocar em atitudes facciosas.

Após a primeira parte, a Epístola abordou muitas outras tensões. No entanto, para se entender bem a nossa perícope de 1 Cor 12, é preciso fazer uma pequena parada em 1 Cor 11,17-34: é o famoso texto das divisões vergonhosas dentro da celebração da Ceia do Senhor. Se a ekklesía deveria se "re-unir" em torno da Ceia do Senhor, se os participante deveriam, sempre, anunciar Jesus Cristo, o que estava acontecendo era um acinte contra os "vis" e "fracos". A celebração da unidade se transformara em momentos de escândalos. Durante a Ceia, os abastados da Igreja reuniam-se para "comer" e "embebedarse" entre eles. No entanto, mais tarde, quando chegavam os trabalhadores e, provavelmente cristãos escravos, não havia mais nada para expressar a vida comunitária. Os ricos já haviam consumido tudo e já estavam bêbados. Não havia Eucaristia.

Então, quando se chegou ao capítulo doze, os leitores de Corinto já tinham se deparado e relembrado de muitas contradições dentro da ekklesía. Ele iniciou 1 Cor 12 mostrando qual era a linguagem daquele que conduzia a Igreja: era a linguagem do Amor. Vendo o Espírito Santo dentro da comunidade, aí poderiam entender os "dons" doados por ele, a cada um, sempre a serviço da construção comunitária. O Apótolo começou a aprofundar a teologia de "um só corpo" (1 Cor 12,12-13) e, então, apresentando o Hino Batismal, 
ele sinalizou que o Espírito fazia o seu campo de ação dentro da Igreja, sem divisões. Isso fora fundamental, porque havia desencontros impestuosos que envolviam os glossolálicos e, também, os espiritualistas/esclarecidos e, com isso, a experiência de "um só corpo" não era levada a sério.

Havia necessidade de denunciar as diversas contendas que se apresentavam naqueles pequenos grupos de Corinto. Para isso, o Apóstolo enfocou-se na espinha dorsal da ekkesía. Estavam acontecendo contradições alí dentro. Qual foi o anúncio de esperança? Era possível aprofundar a "imagem do corpo" e mostrar que Deus tinha a opção preferencial pelos "mais fracos", os "menos dignos" e os "menos decentes" (v. 22-23). Eles eram os seus escolhidos. Na metáfora do corpo ele nominou alguns membros como o "pé", a "mão", a "orelha", o "olho", o "ouvido", o "olfato", a "cabeça" (vv. 14-21).

Ele foi apresentando a riqueza da diversidade. Qualquer corpo tem membros diferentes. Se assim não fosse, não haveria corpo (v. 19). Era aí que estava a questão primordial. A tentação dos abastados era que tudo formasse um só membro. Com essa ideia, os "melhores" controlariam todos e tudo giraria em torno deles. De fato, era isso que estava acontecendo, conforme os relatos dos enviados da "casa de Cloé" (1 Cor 1,11). Paulo jamais aceitou a concepção de um só membro (v. 14).

A imagem do corpo, concretamente, denunciava a presença de vários problemas. Um espiritualista/esclarecido poderia dizer: "trabalhador do porto eu não sou, logo não pertenço ao corpo" (Igreja que Paulo anunciava) (v. 15). Um glossolálico poderia afirmar: "escravo eu não sou, logo não pertenço ao corpo" (a mesma igreja do Crucificado que acolhia a todos) (v. 16). Então, a pergunta nevrálgica do Apóstolo: "Se o corpo todo fosse, por exemplo, de Cefas, onde estariam os seguidores de Cristo?" (v.17a). "Se fossem todos de Apolo, onde estariam os que não o ouviram" (v. 17b). O v. 18 é primordial para se compreender a teologia de Paulo: “...Deus dispôs cada um dos membros no corpo, segundo a sua vontade" (v. 18).

É Deus quem chama. A iniciativa é dEle. Não era um projeto de alguns membros arrogantes da ekklesía de Corinto. A prepotência não fazia parte dos planos de Deus para dinamizar a comunidade. Ninguém podia aproveitar dos cristãos para projeção pessoal ou do grupo. Foi por isso que Paulo denunciou os "partidos" (1 Cor 1,12) dentro da igreja. Quem assim agia, destruía a unidade. Quem se obstinava pelo poder eram os "fortes" (ricos, filósofos, masculinos, gregos, romanos, judeus, senhores), os "perfeitos" que achavam que nada atingia o seu "ego" (1 Cor 6,12; 10,23) e os que tinham "liberdade", 
mas não se preocupavam com os pequenos. Esses se consideravam superiores aos "fracos".

Porém, o anúncio era claro: a comunidade era do Espírito Santo (1 Cor 3,5-7). Foi incrível como o Apóstolo insistiu tanto na visão de que a ekklesía era do Espírito Santo (1 Cor 3,16-17). Ele a chamava de "templo de Deus" e que ela era morada dEle. Daí, o apelo contínuo de que era na igualdade que todos os membros formavam um só corpo.

Ele via a importância da diversidade. O que ele queria era que os grupos avançassem na compreensão da diversidade e labutassem para que todos os membros tivessem total e igual participação. Aí, sim, proclamava-se a clareza de um só corpo. Nessa dialética, ele apelava para que houvesse um grande esforço pela unidade comunitária.

A unidade só iria acontecer, de fato, quando houvesse a preocupação com os "fracos". Quando um grande dizia: "Não preciso de ti (vós)" estava excluindo os pequenos. É de se chamar a atenção o fato de que quem afirmara que não precisava do outro foram o "olho" e a "cabeça". O que estaria por trás das palavras? O olho não podia significar os "esclarecidos" de Corinto que rejeitavam a "mão"? A mão não poderia ser uma referência clara aos trabalhadores braçais dos portos de Corinto? A "cabeça" não podia significar os "espiritualistas" e "glossolálicos" ou mesmo os embrionários gnosticistas que tinham a ânsia por posição, por autoridade, ou mesmo os líderes que estavam à frente de uma forte oposição à linha de preocupação de Paulo pelos excluídos de Corinto? A referência aos "pés" não podia, também, retratar os "doqueiros" que descarregavam e carregavam os navios bem como os "diolcoi" que transportavam os barcos dos ricos de um porto para o outro, através de paus roliços, num esforço descomunal e, à noite, achavam um tempo para irem celebrar a Ceia do Senhor?

Paulo, ao renunciar a uma possível garantia econômica porque tivera oportunidades e, ao se converter a um trabalho manual (tecelão de rede e de tendas), juntamente com Priscila e Áquila, deixando de lado o esquema do modo de produção escravagista romano, tinha uma experiência do que era viver como pobre e com os pobres. Quando ele, concretamente, fez a opção pelos "marginalizados" de Corinto, ele armazenava, de sobra, experiência para dizer no v. 22 que "os membros do corpo que parecem mais fracos são os mais necessários" e no v. 23, que "aqueles que parecem menos dignos de honra do corpo são os que cercamos de maior honra, e nossos membros que são menos decentes, nós os tratamos com mais decência". 
É preciso recordar como era a superestrutura econômica do Império. O modo de produção romano era escravagista. Ele controlava todo Ocidente em torno do Mediterrâneo. Do norte da África ao atual Reino Unido, da Península Ibérica aos arredores do Tigre e Eufrates, toda economia se movia em torno e para Roma. Era uma assimetria econômica e social rígida. Os povos subjugados podiam viver sem grandes conflitos, preservando sua cultura e religiões, se não criassem problemas à economia escravagista do centro do Império. Em toda parte, Roma estava presente com o seu "patronato" e com a presença das Legiões romanas. É nesse aspecto que se precisa entender o controle de Corinto pelo "patronato" romano. Este manipulava a ideologia e a economia, mostrando que Roma estava, de certo modo, presente na grande metrópole do istmo ${ }^{8}$. Por isso, a importância de se compreender a força do "patronato" .

O Apóstolo, quando escreveu a Epístola aos Coríntios, tinha um grande conhecimento da geografia do Império. Além de ter sido um especialista do judaísmo, conhecia, também, a força humanística e pensamental da civilização grega. Enquanto, na sua itinerância, ia anunciando o Evangelho; ele se deparava com as agressivas contradições econômicas, militares e sociais do sistema imperial. Ele, pessoalmente, com alguns outros missionários nunca entrou no esquema escravagista. Ele sobreviveu fora do sistema. Com isso, com uma interessante visão de conjuntura internacional, ele percebia que, no interior da ekklesía de Corinto, manifestavam-se as contradições semelhantes às imperiais.

Entre essas, ele percebia que alguns "fortes" reproduziam o espírito faccioso, preconceituoso e classista dos gregos e romanos. Quando ele denunciou os discricionários, nos vv. 22-23, não estava ele vendo os "vis" que pareciam ser "menos dignos de honra", não estava percebendo os "maginalizados" que pareciam "de menos decência"? Paulo não estaria se inclinando para os trabalhadores e escravos de Corinto e de todo o Império?

\footnotetext{
${ }^{8}$ CHOW, J. K. "Patronato na Corinto Romana". In: HORSLEY, R. A. (Org.). Paulo e o Império: religião e poder na sociedade imperial romana. São Paulo: Paulus, 2004, pp. 111-129; LAMPE, P. "Paulo, os patronos e os clientes". In: SAMPLEY, J. P. (Org.). Paulo no mundo greco-romano: um compêndio. São Paulo: Paulus, 2008, pp. 429-457.

${ }^{9}$ Eis aqui mais dados, além da nota 1 deste artigo: Na pirâmide do sistema romano estava o "imperador". Depois, a "ordem senatorial". Um pouco abaixo o "patronato" que era o grupo social mais importante e que estava presente em todo o império, inclusive em Corinto. A pirâmide continua com muitos estratos sociais. Lá embaixo, os "livres" que eram trabalhadores, campesinos, artesãos, doqueiros, pedreiros etc. e, mais abaixo ainda, fora da pirâmide, os “escravos” (FERREIRA, Joel A. Primeira Epístola aos Coríntios, pp. 23-24).
} 
Hoje, como se conhece bem a Biologia, poder-se-ia dar o exemplo da glândula hipófise. Ela é tão minúscula e, no entanto, se ela não funcionar bem, todo o organismo ficará desequilibrado. Os "fracos", os "vis" e os "marginalizados" seriam a hipófise do corpo da Igreja. Ora, se os trabalhadores e escravos eram abandonados dentro da ekkesía, aí não havia Igreja viva, mas grupos sectários.

Ali, via-se um embrião da Teologia da Libertação, quando, com uma consciência de fé crítica, ele tomou as dores dos que estavam abaixo da pirâmide imperial: "Os mais fracos são os mais necessários e os menos dignos de honra, nós os cercamos de mais honra, os menos decentes, nós os tratamos com mais decência" (vv. 22-23). Aí estava o aceno explícito aos "fortes" da ekklesía, aos masculinos, aos filósofos desencarnados da realidade, aos glossolálicos, aos abastados no nível social e econômico e aos arrogantes da assembléia (v. 21-24): A opção pelos "fracos" era um programa do Apóstolo e seu grupo de missionários itinerantes.

Se o v. 25 chamou a atenção para "solidariedade" para se superar as divisões, o v. 26 assinalou uma dimensão política na comunidade, ao dizer que "se um membro sofre, todos os membros compartilham o seu sofrimento; se um membro é honrado, todos os membros compartilham a sua alegria." A comunidade de Corinto tinha que se transformar.

É preciso, agora, olhar o conceito de "corpo" para se identificar com o pensamento do Apóstolo, que tinha um apelo de conversão aos "fortes" da ekklesía de Corinto.

O termo "sôma" (corpo), por cinquenta e seis vezes, está presente nas duas Epístolas aos Coríntios. A questão devia ser, além de profunda, problemática. No interno da ekklesía Paulo teve que trabalhar o conceito, particularmente diante dos "espiritualistas/esclarecidos", dos "glossolálicos" e dos "pré-gnósticos", que começavam a ter experiências com o Cristianismo.

Paulo, pelo menos, por cinco eixos, abordou o conceito "corpo":

a) Nas tensões com os espiritualistas/esclarecidos;

b) Na vida sexual;

c) Na última Ceia;

d) Na ressurreição;

e) Na visão da ekklesía como "corpo de Cristo".

É sobre esse último eixo que se quer, agora, falar um pouco mais, a partir 
do v. 27: “ora, vós sois o 'corpo de Cristo' e sois os seus membros, cada um por sua parte".

A nossa perícope veio desenvolvendo a conceituação comunitária de que todos são membros de um só corpo (1 Cor 12,14-21). O grande esforço do Apóstolo era buscar a unidade, no meio de tantas tensões e facções internas. Se se reparar bem, Paulo queria, ao lado da unidade, outro conceito vital para diferenciar os cristãos de Corinto dos outros habitantes: a solidariedade. Para a ekklesía, vieram estrangeiros (gregos), judeus, livres do Império, escravos (v. 13: hino batismal), homens, mulheres (1 Cor 7), pessoas que vieram de várias tendências, glossolálicos, espiritualistas/esclarecidos, fracos etc. Era um "corpo" bem diversificado. Todos haviam recebido o batismo. Todos, possivelmente, precisariam caminhar num tipo de vida diferente: na mentalidade do Espírito Santo. Dentro desse "espírito" era possível que tantos diferentes pudessem coexistir, na unidade e na solidariedade. Cada membro, na sua decisão pessoal pelo Evangelho precisaria assumir a comunidade maior, porque ela era o "corpo de Cristo" (v.27). A perspectiva vital do indivídulo, totalmente pessoa, deveria sair do enclausuramento do individualismo para a dimensão maior que era fazer parte, intensamente, da grande comunidade, o "Corpo de Cristo" ou "corpo-comunidade".

Era neste projeto que Paulo acreditava e anunciava: afastava-se da mundividência isolada e individualista que superava a mentalidade greco-romana e superava, mais ainda, a mentalidade estreita dos "fortes" da ekklesía.

Murphy-O'Connor distingue o corpo individual e o eclesiástico ${ }^{10}$. Ele chamou a atenção, fazendo a distinção entre dois corpos de Cristo: o individual, distinto dos fiéis, no qual ele ressuscitou, e o corpo eclesiástico que consiste em fiéis onde ele habita na terra, por intermédio do seu Espírito. Com essa distinção, a comunidade corpo de Cristo se identifica como a presença física de Cristo no mundo. Ela é a ekklesía (1 Cor 1,2). Falou-se, antes, que ele se concretiza na base da unidade e da solidariedade. O Apóstolo insistiu no conceito "amor" (1 Cor 13), que é sempre explicitado na linha do "serviço", porque cada um tem um "dom" espiritual diferente do outro.

Em vários momentos, a Primeira Epístola aos Coríntios mostrou os diversos ecos na compreensão da comunidade como "corpo de Cristo". Aqui nós nos servimos de Van de Born, para se entender como o "nosso corpo" e

${ }^{10}$ MURPHY-O'CONNOR, Jerome. Paulo Biografia Crítica. São Paulo: Ed. Loyola, 2000, p. 293. 
"a nossa pessoa" se tornam equivalentes porque a realidade concreta da vida humana e a íntima constituição da personalidade são corporais ${ }^{11}$.

Aqui se pontuou o teológico mais que o antropológico. Já que, pelo batismo, o corpo (comunidade) é o templo do Espírito Santo e a Comunidade precisa lutar para viver na unidade e no amor, e é inadmissível que contendas internas tenham que ser resolvidas em um processo jurídico (1 Cor 6,7). Não se pode imaginar que, na "Ceia do Senhor", os abastados escandalizem a comunidade comendo e bebendo, excluíndo os fracos da cerimônia (1 Cor 11,17-34).

\section{Conclusão: optar pelos marginalizados é praticar a Teologia da Libertação (12,22-25)}

Aqui se vê a clareza de ideias e opções do Apóstolo. Paulo poderia se agregar e viver sem preocupações no Império Romano, na civilização grega, nos privilegiados do esquema do patronato e, também, com os influentes da ekklesía. No entanto, nesses quatro versículos, por causa da fé e da sabedoria da cruz, o Apóstolo olhou para o outro lado e para lá ele se inclinou. Ele, numa visão revolucionária, afirmou que os "membros do corpo que parecem mais ‘fracos' são os mais necessários” (v.22). Foi a visão de quem estava junto dos marginalizados e lia a história a partir destes e não dos poderosos. Em seguida (v. 23a), constatou que os “que parecem menos 'dignos' de honra do corpo, são os que cercamos de maior honra". Aqui ele sinalizou que não partilhava com aqueles que queriam viver à custa das aparências ou do jeito de viver dos acomodados. Os "vis" eram desprezados pelos "fortes" e grandes. Para Paulo, no entanto, os "vis" eram os honrados porque viviam a seriedade da comunidade.

À frente (23b), ele sinalizou quanto aos "menos decentes". Esses "marginalizados" pelo sistema e, também, pela ekklesía, eram seres humanos e, portanto, Deus concedia maior "honra" para eles (v.24). Paulo não tergiversou: sua opção pelos fracos, vis e marginalizados, por causa do projeto de Deus, era clara. Se os excluídos eram os preferidos de Deus, não se podia

\footnotetext{
${ }^{11}$ Por isso, segundo ele (BORN, V. D. “Corpo”. In: BORN, V. D. (Org.). Dicionário Enciclopédico da Bíblia. Petrópolis: Vozes, 1971), "o vosso corpo é o templo do Espírito de Deus" (1 Cor 6,19), tem o mesmo sentido que "vós sois o templo de Deus e seu Espírito mora em vós" (1 Cor 3,16$)$. E a assertiva "os vossos corpos são membros de Cristo (1 Cor 6,15) equivale a "vós sois membros do corpo de Cristo" (1 Cor 12,27).
} 
imaginar "divisão" no seio da ekklesía (v. 25). A Teologia da Libertação do Apóstolo clamou a todos para terem "igual solicitude" também com os abaixo da pirâmide social. Durante toda a Epístola aos Coríntios, Paulo se indignava com aqueles que, dentro da comunidade, excluíam os marginalizados. A ekklesía não podia viver com os critérios das mentalidades gregas e romanas. $\mathrm{Na}$ comunidade não podia haver prepotentes, arrogantes e soberbos. Esses eram conceitos e práticas colocados dentro de uma sociedade discricionária, de quem se envolvia com o modo de pensar do projeto imperial e seu modo de produção escravagista. Dentro da ekklesía, alguns elementos pertencentes aos grupos "fortes" (1 Cor 1,26-31; 9,19-22), como os iluminados, os glossolálicos, os pré-gnósticos colocavam-se, na prática, como superiores aos simples e humildes da comunidade ("fracos"). A realidade não demonstrava a experiência fraternal dos primeiros cristãos de Corinto.

Quando Paulo anunciara o "Crucificado", o princípio da nova sabedoria entre os gregos e os romanos (1 Cor 1,24), quis mostrar que Ele era o critério para o discernimento. Essa sabedoria era, totalmente, diferente da dos filósofos estoicos e epicureus. Ela se efetivava na comunhão das diferenças. Isto é, embora houvesse várias manifestações das distâncias de classes, o Apóstolo mostrava que o Evangelho era o caminho do amor (agapè) que devia mudar as relações humanas dentro daquela cidade cosmopolita e dentro dos pequenos grupos cristãos.

Por isso, era, com veemência, necessário proclamar a "sabedoria da cruz". Para o pequeno cristianismo, estava vindo gente de outras culturas, credos e pessoas evangelizadas por líderes diversos (Cefas, Apolo, Paulo). Paulo estava mostrando que, assim como Jesus foi para a Cruz, também os trabalhadores e escravos da grande Corinto também estavam, de fato, sendo crucificados na realidade da vida comunitária. Ele via as "contradições" da Civilização Grega e do Império ${ }^{12}$.

Olhando pelos vieses da sociologia e teologia, ao escrever esses versículos $(12,22-23)$, percebe-se que ele estava refletindo sobre o pesado modo de produção escravagista imperial e, aí dentro, vendo os escravos romanos e os desfavorecidos da ekklesía que deveriam ser tratados com

\footnotetext{
12 Baseando-se no escravagismo, os controladores do esquema imperial eram muito severos com os subjugados e, especialmente, com os que estavam abaixo da base da pirâmide (ROSTOVTZEFF, M. Social and Economic History of the Roman Empire. v.2. Oxford: Clarendon Press, 1974, pp. 31ss; MACMÜLLEN, Ransay. Les Repports entre les Classes Sociales dans l'Empire Romain. 50 av. J.C. 284 ap J.C. Paris: Ed. du Seuil, 1986, pp. 73ss), a grande legião de escravos.
} 
"mais decência". Era o Apóstolo fazendo uma decisão definida pelos injustiçados.

Em vez de anunciar a "fácil" e cômoda sabedoria intelectual grega, ele proclamava a Sofia da Cruz. Era essa que devia orientar as consciências dos novos cristãos. Jesus não podia continuar sendo crucificado nos trabalhadores "livres" e nos escravos. Se o Evangelho era o anúncio da "sabedoria" cristã, por que, dentro da comunidade, alguns arrogantes, repetindo o esquema dos "grandes da terra" estavam discriminando os fracos, os vis e marginalizados? Para haver a realização do igualitarismo (1 Cor 12,13) nenhum membro podia reproduzir as injustiças romanas. A práxis era contraditória.

Daí, a grande dificuldade do Apóstolo. Os "fortes" não queriam escutar estas palavras incômodas, porque elas levavam a "correr o risco de vida" (1 Cor 4,9-12). Por isso, que o texto disse que o "olho" e a "cabeça" agiam com prepotência contra os minúsculos órgãos do corpo.

É bom lembrar que um grupo significativo da ekklesía de Corinto rejeitou Paulo. Exatamente porque ele estava do lado das desprezíveis glândulas da comunidade (marginalizados). Defender os da margem nunca atrai público. A firmeza dele era de que "os membros do corpo que parecem mais fracos são os mais necessários” (1 Cor 11,22). Paulo não suportava a eliminação dos "vis" da trajetória da igreja. Aqueles injustiçados eram seres humanos. O apelo da "solicitude de uns com os outros", envolvia a inclusão, pelo menos, dentro da ekklesía, dos infelizes injustiçados.

Por isso, que o Apóstolo, por diversas vezes, chamou a comunidade de "templo de Deus" (1 Cor 3,16-17; 6,19; 12,27). Se ela entendesse isso, sempre colocaria Jesus "Crucificado", como referencial. Por conseguinte, os "crucificados" do Império e da Comunidade, os mais inúteis, também, seriam referenciais, porque eram mais preciosos e, além disso, eram os que mais precisavam dos cuidados dos irmãos.

Então, a denúncia da Ceia do Senhor (1 Cor 11,17-34), onde se explicitava o sectarismo e discriminação dos pobres trabalhadores e escravos não poderia, jamais, ser repetida na comunidade cristã. Era preciso que o olho, a cabeça, as mãos, os pés e todos os órgãos, especialmente os mais escondidos e pequeninos, formassem a "casa de Deus", porque esta era a morada do Espírito Santo (1 Cor 6,19). Os "escondidos" e "pequeninos" estavam nas periferias de Corinto e do império. Foram eles que, no silêncio, explicaram melhor a realidade. 


\section{Referências bibliográficas}

BARBAGLIO, G. As Cartas de Paulo (I). São Paulo: Loyola, 1989.

BORN, V. D. “Corpo”. In: BORN, V. D. (Org.). Dicionário Enciclopédico da Bíblia. Petrópolis: Vozes, 1971.

BRADLEY, K. R. Slaves and Masters in the Roman Empire. A Study in Social Control. New York: Osford University Press, 1987.

CHOW, J. K. "Patronato na Corinto Romana". In: HORSLEY, R. A. (Org.). Paulo e o Império: religião e poder na sociedade imperial romana. São Paulo: Paulus, 2004.

CROSSAN, J. D.; REED, J. L. Em busca de Paulo: como o apóstolo de Jesus opôs o Reino de Deus ao Império Romano. São Paulo: Paulinas, 2007.

FERREIRA, Joel A. Primeira Epistola aos Coríntios. São Paulo: Fonte Editorial, 2013.

LAMPE, P. "Paulo, os patronos e os clientes". In: SAMPLEY, J. P. (Org.). Paulo no mundo greco-romano: um compêndio. São Paulo: Paulus, 2008.

MACMÜLLEN, Ransay. Les Repports entre les Classes Sociales dans l'Empire Romain. 50 av. J.C. 284 ap J.C. Paris: Ed. du Seuil, 1986.

MURPHY-O'CONNOR, Jerome. Paulo Biografia Crítica. São Paulo: Ed. Loyola, 2000.

MURPHY-O'CONNOR, Jerome. "Primeira Carta aos Coríntios". In: BROWN, Raymond E.; FITZMYER, Joseph A.; MURPHY, Roland E. (Eds.). Novo Comentário Bíblico São Jerônimo: Novo Testamento e Artigos Sistemáticos. Santo André/São Paulo: Academia Cristã/Paulus, 2011.

ROSTOVTZEFF, M. Social and Economic History of the Roman Empire. v.2. Oxford: Clarendon Press, 1974.

TAMBASCO, Anthony J. In the Days of Paul. The Social World and Teaching of the Apostle. Eugene, Oregon: Wipf \& Stock, 2006. 
Joel Antônio Ferreira Doutor em Ciências da Religião pela UMESP Pós-Doutor em Ciências Bíblicas pela Universidade de Georgetown de Washington D.C. Professor Titular da Pontifícia Universidade Católica de Goiás Goiânia / GO - Brasil E-mail: joelantonioferreira@hotmail.com

Recebido em: 25/09/16 Aprovado em: 01/12/16 